\title{
Analgesic, anti-inflammatory and anti-pyretic activities of methanolic extract of Cordyline fruticosa (L.) A. Chev. leaves
}

\author{
Sharmin NAHER 1 (D), Md. Abdullah AZIZ 1* (D), Mst. Irin AKTER 2 (D), S.M. Mushiur RAHMAN 1 (D), \\ Sadiur Rahman SAJON 1 (D)
}

1 Department of Pharmacy, Jashore University of Science and Technology, Jashore-7408, Bangladesh.

2 Department of Pharmacy, Stamford University Bangladesh, 51, Siddeswari Road, Dhaka-1217, Bangladesh.

* Corresponding Author. E-mail: a.aziz@just.edu.bd (M.A.A.); Tel. +8801759564289.

Received: 20 June 2018 / Revised: 02 November 2018 / Accepted: 03 November 2018

\begin{abstract}
Traditionally Cordyline fruticosa (L.) A. Chev. is being used for the treatment of various disorders, such as fever, headache, diarrhea, coughs, haemoptysis, small pox, madness, skin eruptions, joint pains, rheumatic bone pains, swelling pain and it is also used for abortion. The aim of our study wast o evaluate analgesic, anti-inflammatory and anti-pyretic activities of methanolic extract of C. Fruticosa leaves (MCFL). Analgesic effect of MCFL was investigated by using acetic acid induced writhing test, formalin-induced paw licking test, tail immersion test and hot plate test. The anti-inflammatory activity was assessed by using xylene induced ear edema test and cotton pellet induced granuloma test, whereas antipyretic effect was observed by utilizing Brewer's yeast-induced pyrexia test. In analgesic test, MCFL significantly $\left({ }^{*} \mathrm{p}<0.05\right.$, vs. control) reduced paw licking and abdominal writhing of mice in a dose dependent manner. MCFL at a dose of $800 \mathrm{mg} / \mathrm{kg}$ body weight, significantly increased pain threshold in tail immersion test and hot plate test. Significant anti-inflammatory effect was produced by MCFL by reducing xylene induced air edema and cotton pellet induced granuloma in a dose dependent manner. In anti-pyretic test, after 4th hour of respective treatment, MCFL at all doses exhibited anti-pyretic activity, when compared with control $(* p<0.05$, vs. control). The results obtained demonstrate that C. fruticosa may provide a source of plant compounds with analgesic, anti-inflammatory and antipyretic activities.
\end{abstract}

KEYWORDS: Cordyline fruticosa; analgesic; anti-inflammatory; anti-pyretic.

\section{INTRODUCTION}

Pain and inflammation are reactions against harmful stimuli, infection, trauma, or injury in the living tissues [1]. Inflammatory mediators such as, cytokines, histamine, serotonin, leukotrienes, and prostaglandins play key roles in creating pain and inflammation [2]. Body shows inflammatory response as a part of defense mechanism to eradicate noxious stimuli as well as to initiate tissue repair [3]. Depending on the duration and pathological condition associated with inflammation, it can be divided into two types: acute or chronic [4]. As inflammation is an important part of damaged tissue repairing process, so any imbalance in regulation of inflammatory response may worse the tissue damage which may lead to serious chronic diseases [5]. Pyrexia or fever is defined as the raising of body temperature above normal range due to induction of PGE2 synthesis in hypothalamus, which occursowing to discharge of ILs, TNF-a and interferon. Moreover, induction of PGE2 synthesis play a vital role in all three cases: inflammation, pain and fever [6]. Non-steroidal anti-inflammatory drugs (NSAIDs) act by inhibiting PGE2 synthesis. When NSAIDs are used for treating inflammation, pain and fever, then they may show several side effects [7-8]. Gastrointestinal ulceration, fluid retention, bronchospasm, and prolongation of bleeding time are common side effect of NSAIDs, while opioids develop addiction and dependency as a side effect during the clinical use of these drugs $[2,9]$. Therefore, searching of agents with better safety and efficacy profile can overcome the limitation of commonly prescribed NSAID drugs [8]. Under such circumstances, traditional medicinal plants can be a dependable source for the management of various diseases [10].

Cordyline fruticosa (L.) A. Chev. (or Cordyline terminalis (L.) Kunth) (Family: Agavaceae) is commonly recognized as good luck plant or Ti plant. It is an evergreen flowering plant having glossy green leaves or its leaves are diversified with red, pink, purple, maroon, yellow, rose, orange. Besides, it is widely distributed

How to cite this article: Naher S, Aziz MA, Akter MI, Rahman SMM, Sajon SR. Analgesic, anti-inflammatory and anti-pyretic activities of methanolic extract of Cordyline fruticosa (L.) A. Chev. leaves. J Res Pharm. 2019; 23 (2): 198-207. 
in tropical and subtropical regions of the world [11-12]. Traditionally the plant has been found to represent itself as a treatment option for various disorders, such as fever, headache, diarrhea, coughs, haemoptysis, small pox, madness, skin eruptions. It is also used in joint pains, rheumatic bone pains and swelling pain which are originated from sprains. The leaves and stem of this medicinal plant was also used for abortion [12].

Phytochemical study of $C$. fruticosa, revealed the existence of various structurally different compounds, such as cholestane glycosides, polyphenols, flavonoid, glucofructan, tannins, alkaloids, steroidal saponins and phytosterols. Pharmacological study showed that the plant has antioxidant, antibacterial and antigastric cancer activities [12-18].

Therefore, considering the traditional use of this medicinal plant, the study was conducted to assess analgesic, anti-inflammatory and antipyretic activities of methanolic extract of $C$. fruticosa leaves.

\section{RESULTS}

\subsection{Acute toxicity study}

During the 14-days observation period, neither abnormal behavior nor mortality was detected in mice, receiving doses up to $3200 \mathrm{mg} / \mathrm{kg}$ of MCFL. In case of control group, similar result was obtained. This indicates that experimental animals do not experience acute oral toxicity at the tested doses $(200,400$ and 800 $\mathrm{mg} / \mathrm{kg}$ ) of MCFL.

\subsection{Analgesic study}

\subsubsection{Acetic acid-induced writhing test}

The results of acetic acid-induced writhing test are presented in Table 1. Mice of all groups, treated with MCFL (200 mg/ kg, $400 \mathrm{mg} / \mathrm{kg}$ and $800 \mathrm{mg} / \mathrm{kg}$ respectively) and diclofenac sodium (DS) (100 mg/kg) showed significant percentage inhibition of writhing $\left({ }^{*} \mathrm{p}<0.05\right.$, versus control). Inhibitory effect of standard (DS, $100 \mathrm{mg} / \mathrm{kg}$ ) was higher than every dose of the extract. MCFL at a dose of $800 \mathrm{mg} / \mathrm{kg}$ showed the highest percentage inhibition of writhing $(71.72 \pm 10.11 \%)$ when compare with MCFL at a dose of $(200 \mathrm{mg} / \mathrm{kg}$ and $400 \mathrm{mg} / \mathrm{kg}$ ). Here, MCFL exerted a dose-related increase in percentage inhibition of writhing.

Table 1. Effects of standard, MCFL (200 mg/kg; $400 \mathrm{mg} / \mathrm{kg}$ and $800 \mathrm{mg} / \mathrm{kg}$ ) in acetic acid induced writhing test

\begin{tabular}{lllll}
\hline Group & Dose & n & Number of writhing & Inhibition (\%) \\
\hline Control & $10 \mathrm{~mL} / \mathrm{kg}$ & 5 & $14.2 \pm 0.97$ & $0.00 \pm 0.00$ \\
DS & $100 \mathrm{mg} / \mathrm{kg}$ & 5 & $2.2 \pm 0.49^{*}$ & $84.57 \pm 3.28^{*}$ \\
MCFL & $200 \mathrm{mg} / \mathrm{kg}$ & 5 & $7.2 \pm 0.66^{*} \square$ & $48.91 \pm 4.48^{*}$ \\
MCFL & $400 \mathrm{mg} / \mathrm{kg}$ & 5 & $6.6 \pm 1.21^{*} \square$ & $50.72 \pm 12.98^{*}$ \\
MCFL & $800 \mathrm{mg} / \mathrm{kg}$ & 5 & $4.0 \pm 1.37^{*}$ & $71.72 \pm 10.11^{*}$ \\
\hline
\end{tabular}

Values are presented as mean \pm standard error of mean. $\mathrm{n}=5$ mice in each group. ${ }^{*} \mathrm{p}<0.05$, vs. control (Dunnett's $\mathrm{t}$ test); ${ }^{\square} \mathrm{p}<0.05$, vs. DS $100 \mathrm{mg} / \mathrm{kg}$ group (pair-wise comparison by post-hoc Bonferroni test). DS: diclofenac sodium, MCFL: Methanolic extract of Cordyline fruticosa leaves.

\subsubsection{Formalin-induced paw licking}

Table 2 displays the results of formalin-induced paw licking test in mice. Mice treated with diclofenac sodium $(100 \mathrm{mg} / \mathrm{kg})$ or MCFL $\left(200 \mathrm{mg} / \mathrm{kg}, 400 \mathrm{mg} / \mathrm{kg}\right.$ and $800 \mathrm{mg} / \mathrm{kg}$ respectively), significantly $\left({ }^{*} \mathrm{p}<0.05\right.$, versus control) reduced the paw licking time at both acute and delayed phase when compared to the control. It was noticed that the paw licking time of mice was reduced, when it was treated with MCFL $800 \mathrm{mg} / \mathrm{kg}$ rather than MCFL $200 \mathrm{mg} / \mathrm{kg} \& 400 \mathrm{mg} / \mathrm{kg}$ respectively. In this test, MCFL produced analgesic effect in a dose dependent manner but the effect was lower than diclofenac sodium.

\subsubsection{Tail immersion test}

Table 3 shows the results of the tail immersion test. In this test, MCFL at a dose of $800 \mathrm{mg} / \mathrm{kg}$ body weight showed significant increase in latency time at $60 \mathrm{~min}, 120 \mathrm{~min}$ and $180 \mathrm{~min}$ when compared with control $\left({ }^{*} \mathrm{p}<0.05\right.$, versus control). However, tramadol $(10 \mathrm{mg} / \mathrm{kg})$ showed increase in latency time significantly $\left({ }^{*} p<0.05\right.$, versus control) at $30 \mathrm{~min}, 60 \mathrm{~min}$ and $120 \mathrm{~min}$. 
Table 2. Effects of MCFL in formalin-induced licking test

\begin{tabular}{lllllll}
\hline Group & Dose & $\mathbf{n}$ & \multicolumn{2}{c}{ Acute phase } & \multicolumn{3}{c}{ Delayed phase } \\
\cline { 3 - 7 } & & & $\begin{array}{l}\text { Licking } \\
\text { time (s) }\end{array}$ & $\begin{array}{l}\text { Inhibition } \\
\mathbf{( \% )}\end{array}$ & $\begin{array}{l}\text { Licking } \\
\text { time (s) }\end{array}$ & $\begin{array}{l}\text { Inhibition } \\
(\%)\end{array}$ \\
\hline Control & $10 \mathrm{~mL} / \mathrm{kg}$ & 5 & $92.2 \pm 2.22$ & $0.00 \pm 0.00$ & $19.8 \pm 1.59$ & $0.00 \pm 0.00$ \\
DS & $100 \mathrm{mg} / \mathrm{kg}$ & 5 & $14.8 \pm 1.35^{*}$ & $83.82 \pm 1.73^{*}$ & $2.2 \pm 0.86^{*}$ & $92.11 \pm 3.29^{*}$ \\
MCFL & $200 \mathrm{mg} / \mathrm{kg}$ & 5 & $43.8 \pm 3.48^{*} \square$ & $52.54 \pm 3.29^{*} \square$ & $16.6 \pm 1.63^{*} \square$ & $43.02 \pm 7.71^{*}$ \\
MCFL & $400 \mathrm{mg} / \mathrm{kg}$ & 5 & $32.4 \pm 2.31^{*} \square$ & $64.69 \pm 2.85^{*} \square$ & $11.8 \pm 0.97^{*} \square$ & $69.77 \pm 4.61^{*} \square$ \\
MCFL & $800 \mathrm{mg} / \mathrm{kg}$ & 5 & $24.8 \pm 1.93^{*}$ & $73.05 \pm 2.14^{*}$ & $7.4 \pm 0.51^{*} \square$ & $74.84 \pm 2.14^{*}$ \\
\hline
\end{tabular}

Values are presented as mean \pm standard error of mean. $n=5$ mice in each group. ${ }^{*} p<0.05$, vs. control (Dunnett's $t$ test); $\square \mathrm{p}<0.05$, vs. DS $100 \mathrm{mg} / \mathrm{kg}$ group; $-\mathrm{p}<0.05$, vs. MCFL $200 \mathrm{mg} / \mathrm{kg}$ group (pair-wise comparison by post-hoc Bonferroni test). DS: diclofenac sodium, MCFL: Methanolic extract of Cordyline fruticosa leaves.

Table 3. Analgesic effect of MCFL in tail immersion test

\begin{tabular}{|c|c|c|c|c|c|c|c|}
\hline \multirow[t]{2}{*}{ Group } & \multirow[t]{2}{*}{ Dose } & \multirow[t]{2}{*}{$\mathbf{N}$} & \multicolumn{5}{|c|}{ Latency time (s) } \\
\hline & & & $0 \mathrm{~min}$ & $+30 \mathrm{~min}$ & $+60 \mathrm{~min}$ & $+120 \mathrm{~min}$ & +180 min \\
\hline Control & $\begin{array}{l}10 \\
\mathrm{~mL} / \mathrm{kg}\end{array}$ & 5 & $1.29 \pm 0.29$ & $1.33 \pm 0.05$ & $1.29 \pm 0.30$ & $1.31 \pm 0.20$ & $1.29 \pm 0.05$ \\
\hline Tramadol & $\begin{array}{l}10 \\
\mathrm{mg} / \mathrm{kg}\end{array}$ & 5 & $1.31 \pm 0.24$ & $4.60 \pm 0.025^{*}$ & $5.95 \pm 0.28^{*}$ & $4.45 \pm 0.65^{*}$ & $2.91 \pm 0.54$ \\
\hline MCFL & $\begin{array}{l}200 \\
\mathrm{mg} / \mathrm{kg}\end{array}$ & 5 & $2.15 \pm 0.32$ & $2.36 \pm 0.45$ & $2.70 \pm 0.28$ & $2.94 \pm 0.27$ & $3.16 \pm 0.46$ \\
\hline MCFL & $\begin{array}{l}400 \\
\mathrm{mg} / \mathrm{kg}\end{array}$ & 5 & $1.13 \pm 0.05$ & $2.59 \pm 0.61$ & $3.00 \pm 0.55$ & $3.84 \pm 1.15^{*}$ & $4.39 \pm 1.26$ \\
\hline MCFL & $\begin{array}{l}800 \\
\mathrm{mg} / \mathrm{kg}\end{array}$ & 5 & $1.06 \pm 0.22$ & $2.25 \pm 0.61$ & $3.55 \pm 0.95^{*}$ & $3.96 \pm 0.54^{*}$ & $4.51 \pm 1.15^{*}$ \\
\hline
\end{tabular}

Latency time values are presented as mean \pm standard error of mean. $n=5$ mice in each group. 0 min means 30 min before drug administration and $+30 \mathrm{~min},+60 \mathrm{~min},+120 \mathrm{~min}$, and $+180 \mathrm{~min}$ indicate $30,60,120$, and $180 \mathrm{~min}$ after drug administration, respectively. ${ }^{*} \mathrm{p}<0.05$, vs. control (Dunnett's $t$-test). Tests of within-subjects effects conducted by repeated measure analysis of variance reveal that for the factor 'time' calculated $F=12.33$ for all methods and $p$ value is not equal to 0.000 in every case. So time is not highly significant at any level of significance.

\subsubsection{Hot plate test}

The results of hot plate test are presented in Table 4. The results show that MCFL at a dose of 400 and $800 \mathrm{mg} / \mathrm{kg}$ body weight significantly increased latency time $\left({ }^{*} \mathrm{p}<0.05\right.$, versus control) at $180 \mathrm{~min}$. Tramadol $(10 \mathrm{mg} / \mathrm{kg})$ showed increase in latency time at $60 \mathrm{~min}$.

Table 4. Effect of standard and MCFL in hot plate test

\begin{tabular}{|c|c|c|c|c|c|c|c|}
\hline \multirow[t]{2}{*}{ Group } & \multirow[t]{2}{*}{ Dose } & \multirow[t]{2}{*}{$\mathbf{n}$} & \multicolumn{5}{|c|}{ Response latency period (s) } \\
\hline & & & $0 \mathrm{~min}$ & $+30 \mathrm{~min}$ & $+60 \mathrm{~min}$ & $+120 \mathrm{~min}$ & $+180 \mathrm{~min}$ \\
\hline Control & $10 \mathrm{~mL} / \mathrm{kg}$ & 5 & $1.18 \pm 0.24$ & $1.08 \pm 0.22$ & $1.55 \pm 0.29$ & $1.16 \pm 0.26$ & $1.19 \pm 0.21$ \\
\hline Tramadol & $10 \mathrm{mg} / \mathrm{kg}$ & 5 & $0.78 \pm 0.12$ & $1.57 \pm 0.28$ & $2.02 \pm 0.27$ & $1.32 \pm 0.18$ & $1.05 \pm 0.07$ \\
\hline MCFL & $200 \mathrm{mg} / \mathrm{kg}$ & 5 & $0.85 \pm 0.03$ & $1.12 \pm 0.21$ & $1.49 \pm 0.26$ & $1.53 \pm 0.36$ & $1.77 \pm 0.29$ \\
\hline MCFL & $400 \mathrm{mg} / \mathrm{kg}$ & 5 & $0.94 \pm 0.13$ & $1.17 \pm 0.14$ & $1.20 \pm 0.17$ & $1.66 \pm 0.32$ & $2.25 \pm 0.26^{*}$ \\
\hline MCFL & $800 \mathrm{mg} / \mathrm{kg}$ & 5 & $1.25 \pm 0.71$ & $1.43 \pm 0.39$ & $1.74 \pm 0.36$ & $2.03 \pm 0.56$ & $2.47 \pm 0.37^{*}$ \\
\hline
\end{tabular}

Latency time values are presented as mean \pm standard error of mean. $n=5$ mice in each group. 0 min means 30 min before drug administration and $+30 \mathrm{~min},+60 \mathrm{~min},+120 \mathrm{~min}$, and $+180 \mathrm{~min}$ indicate $30,60,120$, and $180 \mathrm{~min}$ after drug administration, respectively. ${ }^{*} \mathrm{p}<0.05$, vs. control (Dunnett's $t$-test).Tests of within-subjects effects conducted by repeated measure analysis of variance reveal that for the factor 'time' calculated $F=11.296$ for all methods and $p$ value is not equal to 0.000 in every case. So time is not highly significant at any level of significance. 


\subsection{Anti-inflammatory study}

\subsubsection{Xylene-induced ear edema in mice}

Anti-inflammatory effect of MCFL by xylene-induced ear edema in mice is represented in Table 5 . Diclofenac sodium $(100 \mathrm{mg} / \mathrm{kg})$ and MCFL $(200 \mathrm{mg} / \mathrm{kg}, 400 \mathrm{mg} / \mathrm{kg}$ and $800 \mathrm{mg} / \mathrm{kg})$ decreased the xyleneinduced ear edema in mice significantly $\left({ }^{*} p<0.05\right.$, versus control) when compared to the control group. MCFL elicited inhibitory effect in a dose dependent manner.

Table 5. Effects of the standard and MCFL in xylene-induced ear edema test

\begin{tabular}{lllll}
\hline Group & Dose & n & Ear weight differences (mg) & Inhibition (\%) \\
\hline Control & $10 \mathrm{~mL} / \mathrm{kg}$ & 5 & $7.36 \pm 0.24$ & $0.00 \pm 0.00$ \\
DS & $100 \mathrm{mg} / \mathrm{kg}$ & 5 & $2.58 \pm 0.69^{*}$ & $65.00 \pm 8.94^{*}$ \\
MCFL & $200 \mathrm{mg} / \mathrm{kg}$ & 5 & $4.60 \pm 0.37^{*}$ & $37.64 \pm 4.20^{*}$ \\
MCFL & $400 \mathrm{mg} / \mathrm{kg}$ & 5 & $3.38 \pm 0.89^{*}$ & $54.79 \pm 11.81^{*}$ \\
MCFL & $800 \mathrm{mg} / \mathrm{kg}$ & 5 & $2.70 \pm 0.79^{*}$ & $64.45 \pm 10.13^{*}$ \\
\hline
\end{tabular}

Ear weight differences are denoted as mean \pm standard error of mean. $n=5$ mice in each group. ${ }^{*} p<0.05$, vs. control (Dunnett's $t$ test). DS: diclofenac sodium, MCFL: Methanolic extract of Cordyline fruticosa leaves.

\subsubsection{Cotton pellet-induced granuloma formation in mice}

Fffect of MCFL by cotton pellet-induced granuloma formation in mice is displayed in Table 6. DS (100 $\mathrm{mg} / \mathrm{kg}$ ) and MCFL at a dose of $200 \mathrm{mg} / \mathrm{kg}, 400 \mathrm{mg} / \mathrm{kg}$ and $800 \mathrm{mg} / \mathrm{kg}$ body weight, revealed significant $\left({ }^{*} \mathrm{p}<0.05\right.$, versus control) inhibitory effect by cotton pellet-induced granuloma formation in mice. MCFL exerted dose dependent percentage inhibition of granuloma formation.

Table 6. Effects of the standard and MCFL in cotton pellet induced granuloma test

\begin{tabular}{lllll}
\hline Group & Dose & $\mathbf{n}$ & $\begin{array}{l}\text { Granuloma weight } \mathbf{( m g} / \mathbf{m g} \\
\text { cotton) }\end{array}$ & Inhibition (\%) \\
\hline Control & $10 \mathrm{~mL} / \mathrm{kg}$ & 5 & $38.80 \pm 0.58$ & $0.00 \pm 0.00$ \\
DS & $100 \mathrm{mg} / \mathrm{kg}$ & 5 & $10.40 \pm 0.51^{*}$ & $73.17 \pm 1.31^{*}$ \\
MCFL & $200 \mathrm{mg} / \mathrm{kg}$ & 5 & $21.80 \pm 1.24^{*}$ & $43.89 \pm 2.66^{*} \square$ \\
MCFL & $400 \mathrm{mg} / \mathrm{kg}$ & 5 & $17.80 \pm 2.17^{*}$ & $53.96 \pm 5.81^{*} \square$ \\
MCFL & $800 \mathrm{mg} / \mathrm{kg}$ & 5 & $15.40 \pm 1.16^{*} \Omega$ & $60.16 \pm 3.43^{*} \Omega$ \\
\hline
\end{tabular}

Weights of cotton pellets are presented as mean \pm standard error of mean. $n=5$ mice in each group. ${ }^{*} \mathrm{p}<0.05$, vs. control (Dunnett's t test); ${ }^{\mathrm{p}} \mathrm{p}<0.05$, vs. DS $100 \mathrm{mg} / \mathrm{kg}$ group; $\Omega \mathrm{p}<0.05$, vs. MCFL $200 \mathrm{mg} / \mathrm{kg}$ group (pair-wise comparison by post-hoc Bonferroni test). DS: diclofenac sodium; MCFL: Methanolic extract of Cordyline fruticosa leaves.

Table 7. Antipyretic effects of MCFL

\begin{tabular}{|c|c|c|c|c|c|c|c|c|}
\hline \multirow[t]{2}{*}{ Group } & \multirow[t]{2}{*}{ Dose } & \multirow[t]{2}{*}{$\mathbf{n}$} & \multirow{2}{*}{$\begin{array}{l}\text { Initial rectal } \\
\text { Temperature } \\
\left({ }^{\circ} \mathrm{C}\right)\end{array}$} & \multicolumn{5}{|c|}{$\begin{array}{l}\text { Rectal temperature }\left({ }^{\circ} \mathrm{C}\right) \text { after } 18 \text { h of yeast } \\
\text { injection }\end{array}$} \\
\hline & & & & Oh & 1h & $2 \mathrm{~h}$ & $3 \mathrm{~h}$ & $4 \mathrm{~h}$ \\
\hline \multirow[t]{2}{*}{ Control } & 10 & 5 & 32.72 & 33.76 & 33.40 & 33.38 & 33.28 & 33.2 \\
\hline & $\mathrm{mL} / \mathrm{kg}$ & & \pm 0.63 & \pm 0.67 & \pm 0.42 & \pm 0.44 & \pm 0.44 & \pm 0.46 \\
\hline \multirow[t]{2}{*}{ Paracetamol } & 100 & 5 & 32.26 & 33.38 & 32.48 & 32.46 & 32.16 & 31.84 \\
\hline & $\mathrm{mg} / \mathrm{kg}$ & & \pm 0.64 & \pm 0.67 & \pm 0.50 & \pm 0.54 & \pm 0.50 & \pm 0.43 \\
\hline \multirow[t]{2}{*}{ MCFL } & 200 & 5 & 31.94 & 33.48 & 32.64 & 32.06 & 31.84 & 31.24 \\
\hline & $\mathrm{mg} / \mathrm{kg}$ & & \pm 0.59 & \pm 0.45 & \pm 0.58 & \pm 0.52 & \pm 0.40 & $\pm 0.34^{*}$ \\
\hline \multirow[t]{2}{*}{ MCFL } & 400 & 5 & 32.06 & 33.06 & 33.46 & 32.50 & 32.32 & 31.54 \\
\hline & $\mathrm{mg} / \mathrm{kg}$ & & \pm 0.53 & \pm 0.34 & \pm 0.32 & \pm 0.25 & \pm 0.28 & $\pm 0.13^{*}$ \\
\hline \multirow[t]{2}{*}{ MCFL } & 800 & 5 & 32.74 & 33.48 & 32.08 & 31.94 & 31.58 & 31.36 \\
\hline & $\mathrm{mg} / \mathrm{kg}$ & & \pm 0.54 & \pm 0.51 & \pm 0.41 & \pm 0.62 & $\pm 0.50^{*}$ & $\pm 0.53^{*}$ \\
\hline
\end{tabular}

Rectal temperature values $\left({ }^{\circ} \mathrm{C}\right)$ are presented as mean \pm standard error of mean. $n=5$ mice in each group. Tests of within-subjects effects reveal that for the factor 'Temperature' calculated $\mathrm{F}=15.658$ for all methods and $\mathrm{p}$ value is not equal to 0.000 in every case. So time is not highly significant at any level of significance. ${ }^{*}<<0.05$, vs. control (Dunnett's t test); MCFL: Methanolic extract of Cordyline fruticosa leaves. 


\subsection{Antipyretic study}

Antipyretic effect of MCFL are displayed in Table 7. $18 \mathrm{~h}$ after yeast injection, subcutaneous administration of brewer's yeast raisedthe rectal temperature of mice. MCFL at a dose of $800 \mathrm{mg} / \mathrm{kg}$ significantly $\left({ }^{*} \mathrm{p}<0.05\right.$, versus control) reduced yeast induced pyrexia at $3^{\text {rd }}$ and $4^{\text {th }} \mathrm{h}$, when compared with control. In addition, MCFL at a dose of $(200 \mathrm{mg} / \mathrm{kg}$ and $400 \mathrm{mg} / \mathrm{kg})$ significantly $\left({ }^{*} \mathrm{p}<0.05\right.$, versus control) reduced yeast induced pyrexia at $4^{\text {th }} \mathrm{h}$, when compared with control.

\section{DISCUSSION}

Traditionally many plants or plant-derived products are used for healing purpose, but scientifically approved toxicity studies have been carried out on few of them. So, for the determination of suitable doses range of the experimental materials, acute oral toxicity studies must be performed [19]. The median lethal dose $\left(\mathrm{LD}_{50}\right)$ of the plant extracts could not be obtained up to the dose as high as $3200 \mathrm{mg} / \mathrm{kg}$. As neither mortality nor behavior changes were found during the observation period, so, it may be suggested that the plant extract (MCFL) is relatively safe, or non-toxic to mice. Therefore, three high doses of MCFL (200, 400 and $800 \mathrm{mg} / \mathrm{kg}$ ) were used for in vivo doses.

Four animal models were selected to evaluate analgesic activity of C. fruticosa leaves. Peripheral analgesic effect was evaluated by using acetic acid induced writhing test and formalin induced paw licking test, whereas central analgesic activity was evaluated by using tail immersion test and hot plate test. In the acetic acid-induced writhing test, intraperitoneal injection of acetic acid causes the release of endogenous substances such as PGE2 and PGF2, serotonin and histamine in the peritoneal area. Acetic acid induced increase in prostaglandin E2 and F2a levels in peritoneal fluid excite pain nerve endings [20-21]. MCFL elicited significant analgesic activity in a dose dependent manner when compared with control in acetic acid induced writhing test. Pain inhibitory activity of MCFL may be related to inhibition of prostaglandin synthesis.

Formalin-induced licking test has two phases: acute phase and delayed phase. Acute phase starts immediately or within $5 \mathrm{~min}$ after formalin injection and delayed phase starts within 20 to 25 min after formalin injection. Formalin test assesses the behavioral response of animal through licking, lifting and flinching [22]. During acute phase (also called neurogenic phase), pain results from direct stimulation of nociceptors by formalin. Acute phase (non-inflammatory phase) is thought to be related with the release of substance $\mathrm{P}$, glutamate and bradykinin. In delayed phase (inflammatory phase), several inflammatory mediators, such as histamine, serotonin, prostaglandins and bradykinin are thought to cause inflammatory pain. Both early and late phase of pain are inhibited by centrally acting drugs, such as narcotic analgesics, whereas peripherally acting drugs, such as acetylsalicylic acid inhibitsthe late phase of pain selectively [23]. MCFL may exert its inhibitory effect in both phases of formalin-induced paw licking test by inhibiting pain mediator such as, substance $P$, bradykinins, histamine, serotonin, and prostaglandins.

Hot plate test and tail immersion test are used to assess central analgesic activity [20-21]. Our result demonstrated that MCFL elicited its inhibitory activity by increasing latency time at 120 min that opposed the involvement of opioid. So, MCFL may show peripheral analgesic effect.

For evaluating anti-inflammatory effect of MCFL, two animal models were chosen. Acute antiinflammatory activities were evaluated by using xylene-induced ear edema in mice, whereas cotton pelletinduced granuloma in mice was chosen to evaluate chronic anti-inflammatory activity.

The most common inflammatory model, xylene-induced ear edema was used for evaluating vascular permeability. Ear edema induced by xylene is partially associated with the release of substance P [24].The results of our study elicited that MCFL decreased ear edema in mice significantly in a dose dependent manner, which may occur by inhibitingthe release of substance $P$.

In the cotton pellet-induced granuloma formation, acute inflammatory response is triggered by subcutaneous implantation of cotton pellet. When the acute inflammatory response is insufficient to eliminate the pro-inflammatory agents, then it becomes to chronic inflammation. Proliferation of fibroblasts and the infiltration of neutrophils and mononuclear cells are chronic inflammatory reactions [23]. Responses to cotton pellet implantation can be divided into three phases. Frist phase is called transudative phase, that is defined as the leakage of fluid from blood vessels caused by increasing in vascular permeability. Second phase is called exudative phase, which is defined as the leakage of protein from bloodstream around granuloma caused by the intensive maintenance in vascular permeability change. Third or final phase is known as proliferative phase,that is defined as the production of granulomatous tissues caused by continuous pro-inflammatory mediator release [25]. Steroids show strong inhibitory activity on both the 
proliferative and transudative phases of inflammation, whereas NSAIDs, such as diclofenac sodium, exhibit inhibitory activity only in the proliferative phase of inflammation, by inhibiting PG synthesis [19]. Results of present study show that diclofenac sodium and MCFL significantly reduced cotton pellet induce granuloma formation in a dose dependent manner. MCFL may exert anti-inflammatory effect by suppressing proliferative phase.

Infection, inflammation, graft rejection, or other disease states may be the cause of fever. In the antipyretic test, MCFL significantly reduced rectal temperature of pyretic mice at $4^{\text {th }} \mathrm{h}$. Biosynthesis of prostaglandins (most potent pyretic agent) in the central nervous system is mainly responsible for pyrogen induced fever production [26]. Exogenous pyrogen causes the release of pro-inflammatory cytokines, such as TNF- $\alpha$, IL-1 $\beta$, IFN- $\alpha$ and IL-6. These pro-inflammatory cytokines stimulate the release of PGs, when enter into the hypothalamic circulation [19]. MCFL may exhibit its antipyretic effect by inhibiting prostaglandin biosynthesis in the central nervous system, because prostaglandin may act as a regulator of body temperature [27].

\section{CONCLUSION}

The results of present study indicate that methanolic extract of $C$. fruticosa leaves possess analgesic, anti-inflammatory and anti-pyretic activities. Moreover, genotoxicity study of this plant should be performed to ensure its safety issue.

\section{MATERIALS AND METHODS}

\subsection{Collection and authentication of plant material}

The leaves of Cordyline fruticosa were collected from the village Godkhali, Jhikargacha (at latitude $23.1000^{\circ} \mathrm{N}$ and longitude $89.1333^{\circ} \mathrm{E}$ ), Jashore, Bangladesh in October, 2017. The plant was identified and authenticated by Naimur Rhaman, Senior Scientific Officer, Bangladesh National Herbarium, Dhaka, Bangladesh. A vouncher specimen (DACB: 44989) has been deposited in the herbarium for future reference.

\subsection{Preparation of the methanolic extract}

Collected leaves were washed thoroughly with water and then shade dried at room temperature for a period of 14 days. Fine powders of leaves were obtained by grinding and sieving of dried leaves. These powdered leaves $(500 \mathrm{~g})$ were soaked in methanol $(2.5 \mathrm{~L})$ at room temperature $\left(25 \pm 2^{\circ} \mathrm{C}\right)$ for 14 days. Consequently, the extract was filtered by passing through cotton and Whatman No. 1 filter paper. The filtrate obtained was concentrated with the help of rotary evaporator and then air dried to get solid residue. The final yield of the extract was $4.94 \%(w / w)$.

\subsection{Experimental animals}

All experiments were conducted with Swiss albino mice of either sex (6-7 weeks old), having body weight between 25-30 g. These experimental animals were collected from Jahangirnagar University, Savar, Dhaka, Bangladesh. They were kept in animal house at $22 \pm 2{ }^{\circ} \mathrm{C}$ temperature. Besides, $55 \pm 5 \%$ relative humidity with $12 \mathrm{~h}$ light and $12 \mathrm{~h}$ dark cycle were maintained for animals to ensure standard environmental conditions.The animals were kept in these conditions for at least 1 week before experiment and fed with foods and water ad libitum. All protocols (Protocol No. ERC/FBS/JUST/2017-03) adopted in these experiment were approved by the institutional animal ethical committee of Jashore University of Science and Technology, Jashore, Bangladesh.

\subsection{Acute toxicity study}

Acute toxicity is regarded as the expression of adverse effects that result either from a single exposure or from multiple exposure over a short time $(<24 \mathrm{~h})$. The acute toxicity study was carried out following the method of Aziz for determining $\mathrm{LD}_{50}$ of the experimental sample [19]. In total, ten mice were divided into two groups, containing five mice in each group. MCFL was administered orally in the dose range of 100, 200, $400,800,1600$ and $3200 \mathrm{mg} / \mathrm{kg}$ body weight. Following the above treatment, each group of mice were examined every $1 \mathrm{~h}$ to a period of $6 \mathrm{~h}$, due to finding pain, noisy breathing, mortality, diarrhea, convulsion, salivation, weakness, changes in locomotor activity, coma, aggressiveness, discharge from eyes and ears, injury, food or water refusal etc. At the end of a 14 days monitoring period, a concluding assessment was performed also. 


\subsection{Analgesic study}

\subsubsection{Acetic acid-induced writhing test}

Writhing test was carried out according to the method of Koster et al [28]. Twenty five mice of either sex were divided randomly into five groups, where each group contained five mice. Mice in control group received distilled water orally at a dose of $10 \mathrm{~mL} / \mathrm{kg}$ body weight, while positive control or standard group was treated orally with diclofenac sodium (DS) at a dose of $100 \mathrm{mg} / \mathrm{kg}$ body weight and MCFL was administered to test groups orally at a dose of $200 \mathrm{mg} / \mathrm{kg}, 400 \mathrm{mg} / \mathrm{kg}$ and $800 \mathrm{mg} / \mathrm{kg}$ body weight respectively. After 30 minute, $0.7 \%(\mathrm{v} / \mathrm{v})$ acetic acid at a dose of $10 \mathrm{~mL} / \mathrm{kg}$ body weight was injected intraperitoneally to induce writhing in mice. Fifteen minutes later, the number of writhing was counted over a period of five minute for each animal. Inhibitory activity of writhing was calculated according to this formula:

$$
\text { Inhibition }(\%)=\left[1-\frac{\text { No. of writhing (extract or standard drug) }}{\text { No. of writhing (normal control) }}\right] \times 100
$$

\subsubsection{Formalin-induced paw licking}

Paw licking study was carried out using the method of Hunskaar and Hole [29]. Grouping and treating of mice were doneas described previously. $1 \mathrm{~h}$ later, $20 \mu \mathrm{L}$ of $2.7 \%(\mathrm{v} / \mathrm{v})$ formalin was injected into the dorsal surface of the left hind paw of each mouse. After formalin injection, the time spent for licking the injected paw was recorded in acute phase (0-5 min) and in delayed phase (20-25 min).

The percentage inhibition of granuloma formation was calculated according to this formula:

Inhibition $(\%)=\left[1-\frac{\text { Licking time (extract or standard drug) }}{\text { Licking Time (normal control) }}\right] \times 100$

\subsubsection{Tail immersion test}

Tail immersion test was performed following the method of Toma et al to assess the central mechanism of analgesic activity [30]. The tip of the tail (last 1-2 cm) of mouse was dipped into hot water to generate pain reaction in response to thermal stimulus. Before experiment, animals were screened for sensitivity test and those animals withdraw their tail within $5 \mathrm{~s}$ were selected for the test. Before the experiment, the animals were fasted for $16 \mathrm{~h}$ with water ad libitum. After screening, selected animals were grouped and treated as descried previously, except that tramadol $(10 \mathrm{mg} / \mathrm{kg})$ was used as the standard drug. Latency is defined as, the time taken to withdraw the tip of tail (last 1-2 cm) after immerging it in hot water that is maintained at a temperature of $(55 \pm 1){ }^{\circ} \mathrm{C}$. Latency was recorded from before $30 \mathrm{~min}$ and after $30,60,120$ and $180 \mathrm{~min}$ of the treatment of each group, and latency period (15 s) set as the cutoff point to avoid injury.

\subsubsection{Hot plate test}

The hot plate test was conducted to assess the central mechanism of analgesic activity according to the method of Turner [31]. Prior to the experiment,animal were screened for this test by placing them on hot plate maintained at a temperature of $55 \pm 1{ }^{\circ} \mathrm{C}$ and those animals showed pain response within $5 \mathrm{~s}$ were selected for this test. Selected animals were grouped and treated as descried previously, except that tramadol $(10 \mathrm{mg} / \mathrm{kg})$ was used as the standard drug. The animals were fasted for $16 \mathrm{~h}$ with water ad libitum before experiment. Latency of pain response is defined as, difference of the time between placing the mice on the 
hot plate and forepaw licking, hind paw flicking or jumping off the surface. The cutoff point (15 s) was selected to prevent injury. Measurement of latency was conducted before $30 \mathrm{~min}$ and after 30, 60, 120 and $180 \mathrm{~min}$ of the treatment of each group.

\subsection{Anti-inflammatory study}

\subsubsection{Xylene-induced ear edema}

The method of Dai et al was used to conduct xylene-induced ear edema test [32]. Twenty five mice of either sex were divided randomly into five groups of five mice per group. Control group received distilled water $(10 \mathrm{~mL} / \mathrm{kg}$ body weight) orally, while test groups were treated with MCFL (200, 400 and $800 \mathrm{mg} / \mathrm{kg}$ body weight) orally and standard group received diclofenac sodium (100 mg/ $\mathrm{kg}$ body weight)orally. one hour later, xylene $(20 \mu \mathrm{L})$ was given on the anterior and posterior surfaces of the right ear lobe of each mouse while left ear remain untreated and served as a control. one hour after the application of xylene, mice were sacrificed and $5 \mathrm{~mm}$ circular section of both the left and right ear were taken with the help of cork borer and weighed. The difference between weight of xylene treated ear (right ear) and the weight of untreated ear (left ear) was determined and considered it as the edema induced by xylene.

The percentage inhibition of ear edema was calculated according to this formula:

$$
\text { Inhibition }(\%)=\left[1-\frac{\text { Weight of edema (extract or standard drug) }}{\text { Weight of edema (normal control) }}\right] \times 100
$$

\subsubsection{Cotton pellet-induced granuloma formation}

Cotton pellet-induced granuloma formation test was performed to evaluate chronic or proliferative phases of inflammation following the method of Swingle and Shideman [33]. Under sterile technique, at first day, sterilized cotton pellets weighing $(10 \pm 1) \mathrm{mg}$ each, were put subcutaneously, one on each side of the abdomen of the animal anesthetized with chloroform. Mice were grouped and treated as described before. Moreover, each group of mice received their respective treatment once daily for 7 days from the day of cotton pellets insertion. On the 8th day, mice were sacrificed and cotton pellets were removed and dried at $60{ }^{\circ} \mathrm{C}$ for $24 \mathrm{~h}$. After drying, weight of the dried cotton was measured. The weight of granuloma that was formed by inserting cotton pellet was determined from the weight difference between dried cotton pellets and the cotton pellets before insertion.

The percentage inhibition of granuloma formation was calculated according to this formula:

Weight of granuloma (extract or standard drug)

Inhibition $(\%)=\left[1-\frac{}{\text { Weight of granuloma (normal control) }}\right] \times 100$

\subsection{Brewer's yeast-induced pyrexia test}

Brewer's yeast-induced pyrexia test was conducted to estimate antipyretic activity by using the method of Aziz [19]. Prior to the experiment, mice were fasted for $18 \mathrm{~h}$ with free access to water. An initial rectal temperature of mice was measured using digital thermometer before injecting yeast. To induce pyrexia, $15 \%(\mathrm{w} / \mathrm{v})$ suspension of brewer's yeast $(10 \mathrm{~mL} / \mathrm{kg}$ body weight) was injected subcutaneously in the back below the nape of the neck of the mice and massaged the injection site to spread the suspension under the skin. 18h later, the rectal temperature of mice was measured and those mice showed an increase in temperature of at least $0.6^{\circ} \mathrm{C}$ were considered pyretic mice and selected for the test. Mice of either sex were randomly divided into five groups, containing five mice per group. After inducing pyrexia, control group received distilled water $(10 \mathrm{~mL} / \mathrm{kg}$ body weight), test groups were treated with MCFL (200, 400 and 800 $\mathrm{mg} / \mathrm{kg}$ body weight) and standard group received paracetamol $(100 \mathrm{mg} / \mathrm{kg}$ body weight), where all drugs were received orally. After respective treatment of each group, rectal temperature was measured at 1, 2, 3 and $4 \mathrm{~h}$. 


\subsection{Statistical analysis}

All results are expressed as mean \pm standard error of mean (SEM). Statistical analysis of data was performed using one-way ANOVA followed by Dunnett's $t$-test or post-hoc Bonferroni test. In addition, analysis of result of tail immersion test, hot plate test and brewer's yeast-induced pyrexia test was performed by using repeated measure ANOVA. Value of $p$ lower than $0.05(\mathrm{p}<0.05)$ was considered to be statistically significant. SPSS software (version 20; IBM Corporation, New York, USA) was used to conduct statistical analysis of data.

Acknowledgement: The authors are grateful to the Department of Pharmacy, Jashore University of Science and Technology, Jashore, Bangladesh for providing facilities to carry out the research work.

Author contributions: Concept - S.N., M.A.A.; Design - S.N., S.M.M.R.; Supervision - M.A.A.; Resources - M.A.A., MIA.; Materials - S.N., MIA., S.M.M.R., S.R.S.; Data Collection and/or Processing -S.N., M.A.A., MIA., S.M.M.R., S.R.S.; Analysis and/or Interpretation - S.N., M.A.A., S.R.S.; Literature Search - S.N., MIA., S.M.M.R.; Writing - S.N., M.A.A., MIA.; Critical Reviews - S.N., M.A.A., MIA., S.M.M.R., S.R.S.

Conflict of interest statement: The authors declared no conflict of interest.

\section{REFERENCES}

[1] Rafieian-Kopaei M, Shakiba A, Sedighi M, Bahmani M. The Analgesic and anti-inflammatory activity of Linum usitatissimum in Balb/c mice. J Evid Based Complementary Altern Med. 2017; 22(4):892-896.[CrossRef]

[2] Ishola IO, Agbaje EO, Adeyemi OO, Shukla R. Analgesic and anti-inflammatory effects of the methanol root extracts of some selected Nigerian medicinal plants. Pharm Biol. 2014; 52(9): 1208-1216. [CrossRef]

[3] Cheng J, Yi X, Wang Y, Huang X, He X. Phenolics from the roots of hairy fig (Ficus hirta Vahl.) exert prominent antiinflammatory activity. J Funct Foods.2017; 31: 79-88.[CrossRef]

[4] Sajid M, Khan MR, Shah SA, Majid M, Ismail H, Maryam S, Batool R, Younis T. Investigations on anti-inflammatory and analgesic activities of Alnus nitida Spach (Endl). stem bark in Sprague Dawley rats. J Ethnopharmacol. 2017; 198: 408-416. [Cross Ref]

[5] Huo X, Zhang L, Gao L, Guo Y, Zhang L, Li L, Si J,Cao L. Antiinflammatory and analgesic activities of ethanol extract and isolated compounds from Millettia pulchra. Biol Pharm Bull. 2015; 38: 1328-1336.[CrossRef]

[6] Sengar N, Joshi A, Prasad SK, Hemalatha S. Anti-inflammatory, analgesic and anti-pyretic activities of standardized root extract of Jasminum sambac. J Ethnopharmacol. 2015; 160: 140-148. [CrossRef]

[7] Gupta S, Singh A. Antimicrobial, analgesic and anti-inflammatory activity reported on Tamarindus indica Linn root extract. Pharmacogn J. 2017; 9(3): 410-416. [CrossRef]

[8] Eidi A, Oryan S, Zaringhalam J, Rad M. Antinociceptive and anti-inflammatory effects of the aerial parts of Artemisia dracunculus in mice. Pharm Biol.2016; 54(3): 549-554. [CrossRef]

[9] Paliwal SK, Sati B,Faujdar S, Sharma S. Studies on analgesic, anti-inflammatory activities of stem and roots of Inula cuspidata C.B Clarke. J Tradit Complement Med. 2017; 7(4): 532-537. [CrossRef]

[10] da Costa Oliveira C, de Matos NA, de Carvalho Veloso C, Lage GA, Pimenta LPS, Duarte IDG, Romero TRL, Klein A, de Castro Perez A. Anti-infammatory and antinociceptive properties of the hydroalcoholic fractions from the leaves of Annona crassifora Mart.in mice. Inflammopharmacol.2018;1-12. [CrossRef]

[11] Yokosuka A, Suzuki T, Mimaki Y. New cholestane glycosides from the leaves of Cordyline terminalis. Chem Pharm Bull. 2012; 60(2):275-279.

[12] Lim TK. Cordyline fruticosa. In: Edible Medicinal and Non Medicinal Plants. Springer, Dordrecht, New York, 2015,pp.627-632. [CrossRef]

[13] Fouedjoua RT, Teponno RB, Quassinti L. Steroidal saponins from the leaves of Cordyline fruticosa (L.) A. Chev. and their cytotoxic and antimicrobial activity. Phytochem Lett. 2014; 7: 62-68.[CrossRef]

[14] Dahlia AA, Ahmad AR, Wahid M. Extraction of color pigment and determination of flavonoid content of andong leaves (Cordyline fruticosa L.) source Makassar city. J Biol Sci Opin. 2013; 1 (4): 294-296. [CrossRef]

[15] Fouedjou RT, Nguelefack-Mbuyo EP, Ponou BK. Antioxidant activities and chemical constituents of extracts from Cordyline fruticosa (L.) A. Chev. (Agavaceae) and Eriobotrya japonica (Thunb) Lindl, (Rosaceae). Pharmacologia. 2016; 7: 103-113. [CrossRef] 
[16] Ahmed F, Das PK, Islam MA, Rahman KM, Rahman MM, Selim MST. Antibacterial activity of Cordyline terminalis Kunth. leaves. J Med Sci.2003; 3(5):418-422. [CrossRef]

[17] Liu S, Cao D, Xiao Z, Liu F, Wang X, Zhao L, Tian L, Shen S. A comparative study of anti-gastric cancer activity between aqueous extract and ethanol extract ofFoliumCordylines Fruticosae. Afr J Tradit Complement Altern Med. 2013; 10(4): 78-82.

[18] Reddy BC, Noor A, Sabareesh V, Vijayalakshmi MA. Preliminary screening of potential flavonoid-subclasses in Myristica fragrans and Cordyline terminalis by LC-ESI-MS.J Pharmacogn Phytochem. 2016; 5(6): 437-450.

[19] Aziz MA. Qualitative phytochemical screening and evaluation of anti-inflammatory, analgesic and antipyretic activities of Microcos paniculata barks and fruits. J Integr Med. 2015; 13(3):173-184.[CrossRef]

[20] Zhang L, Hu JJ, Lin JW, Fang WS, Du GH. Anti-inflammatory and analgesic effects of ethanol and aqueous extracts of Pterocephalus hookeri (C.B. Clarke) Höeck. J Ethnopharmacol. 2009; 123(3): 510-514. [CrossRef]

[21] Ma KJ, Zhu ZZ, Yu CH, Zhang H, Liu J, Qin LP. Analgesic, anti-inflammatory, and antipyretic activities of the ethanol extract fromDesmodium caudatum. Pharm Biol. 2011; 49(4): 403-407.[CrossRef]

[22] Lee KH, Choi EM. Analgesic and anti-inflammatory effects of Ligularia fischeri leaves in experimental animals. J Ethnopharmacol. 2008; 120: 103-107. [CrossRef]

[23] Zhao J, Fang F, Yu L, Wang G, Yang L. Anti-nociceptive and anti-inflammatory effects of Croton crassifolius ethanol extract. J Ethnopharmacol. 2012; 142: 367-373. [CrossRef]

[24] Zhou M, Wang H, Suolangjiba, Kou J, Yu B. Antinociceptive and anti-inflammatory activities of Aquilaria sinensis (Lour.) Gilg. leaves extract. J Ethnopharmacol. 2008; 117(2):345-350. [CrossRef]

[25] Pingsusaen P, Kunanusorn P, Khonsung P, Chiranthanut N, Panthong A, Rujjanawate C. Investigation of antiinflammatory, antinociceptive and antipyretic activities of Stahlianthus involucratus rhizome ethanol extract. J Ethnopharmacol. 2015; 162:199-206. [CrossRef]

[26] Panthong A, Kanjanapothi D, Taesotikul T, Phankummoon A, Panthong K, Reutrakul V. Anti-inflammatory activity of methanolic extracts from Ventilago harmandiana Pierre. J Ethnopharmacol. 2004; 91(2-3):237-242.[CrosRef]

[27] Antonisamy P, Duraipandiyan V, Ignacimuthu S. Anti-inflammatory, analgesic and antipyretic effects of friedelin isolated from Azima tetracantha Lam. in mouse and rat models. J Pharm Pharmacol. 2011; 63(8):1070-1077. [CrossRef]

[28] Koster R, Anderson M, De-Beer EJ. Acetic acid analgesic screening. Fed Proc.1959; 18: 412-417.

[29] Hunskaar S, Hole K. The formalin test in mice: dissociation between inflammatory and non- inflammatory pain. Pain. 1987; 30(1): 103-114.

[30] Toma W, Graciosa JS, Hiruma-Lima CA, Andrade CDP, Vilegas W, Souza Brito ARM. Evaluation of analgesic and antiedematogenic activities of Quassia amarabark extract. J Ethnopharmacol.2003; 85: 19-23. [CrossRef]

[31] Turner RA. Analgesics. In: Screening methods in pharmacology. Academic Press, New York \& London, 1965, pp.100-117.

[32] Dai Y, Liu LH. Anti-inflammatory effect of aqueous extract of Wu-Hu-Tang. J China Pharm Uni. 1995; 6: $362-364$.

[33] Swingle KF, Shideman FE. Phases of the inflammatory response to subcutaneous implantation of cotton pellet and their modification by certain anti-inflammatory agents. J Pharm Exp Ther. 1972; 183(1): 226-234. 